\title{
38. Stratigraphic Position of the Corals in the Ichinotani Formation (Carboniferous), Fukuji District, Hida Massif, Central Japan
}

\author{
By Haruyoshi Fujimoto and Hisayoshi Igô \\ (Comm. by H. YABE, M.J.A., March 12, 1958)
}

The Ichinotani formation is a thick limestone formation developed in the Fukuji district, Kamitakara village, Yoshiki county, Gifu prefecture. The junior writer who worked out its stratigraphy and fusulinid fauna could distinguished it in five fusulinid zones, viz., Triticites-, Fusulina-, Fusulinella-, Profusulinella-, and Millerella zones, and collected numerous corals from various horizons. The stratigraphic relation of these corals to the fusulinid zones is treated in this article.

The writers thank Dr. Hisakatsu Yabe, Professor Emeritus, Tôhoku University, for his valuable suggestions, and Mr. Tadao Kamei, Shinshu University, for his co-operation in field. Acknowledgements are also due to the Ministry of Education and the Asahi Press for support defrayed from their Scientific Expenditure Funds.

Stratigraphic position of the corals. Four or five coral faunae are distinguishable in the Ichinotani formation, the oldest of which is from the lower part of the Millerella zone (M. kanmerai zone). The lower limit of this $25 \mathrm{~m}$ thick zone is in fault contact with the Gotlandian. Corals are found in its black impure limestone facies which intercalates thin black shale and siliceous bands. Besides Linoproductus, other large unidentified productids, Millerella, and plectogyroid foraminifera, this zone yielded the following corals.

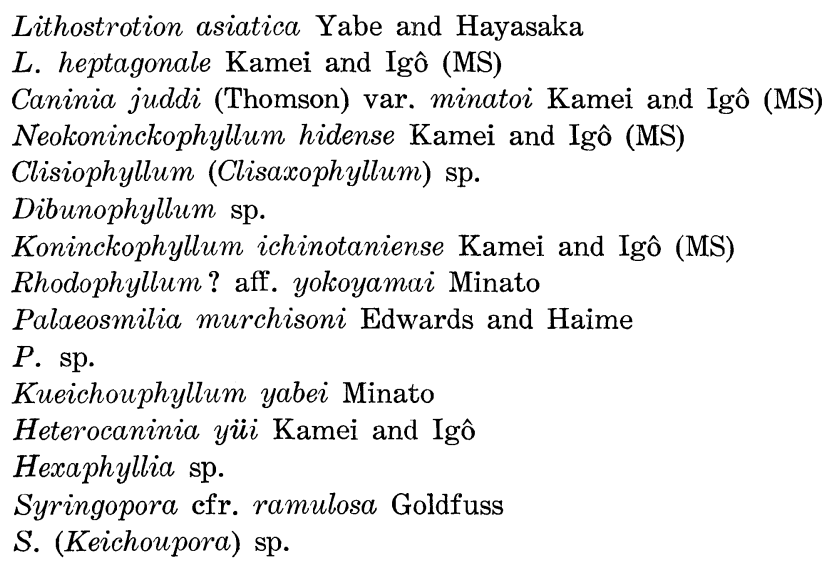

Minato and Kato (1957) studied the coral fauna and reported: Lonsdaleia aff. duplicata duplicata (Martin), L. sp., Rhodophyllum? 
minatoi Kato (MS), Neokoninckophyllum gracile nipponense Kato (MS), Arachnolasma cylindricum Yü, Dibunophyllum sp., Palaeosmilia cfr. murchisoni Edwards and Haime, Heterocaninia sp., Hexaphyllia sp., Syringopora sp.

They assumed that the coral fauna is divisible into two distinct zones, Neokoninckophyllum gracile nipponense zone in the higher position and Siphonodendron hidense zone in the lower. All of the writers' materials are from the same stratigraphic horizon, separation of which into two is practically difficult in field; the view of Minato and Kato is questionable even though they based it on the occurrence of Neokoninckophyllum and other corals of younger type in association.

This coral fauna corresponds to those of the Onimaru formation of the Kitakami massif, the Shangssuan series of South China, and the Upper Visean of Europe on the following reasons: 1) Lithostrotion asiatica, originally from the Shangssuan series of Hunan province, is common throughout the zone of Yuanophyllum of the Lower Carboniferous of China. 2) Lithostrotion heptagonale, a massive form, is intimately related to certain species from the Shangssuan and also from Great Britain. 3) Caninia juddi var. minatoi closely resembles C. juddi which ranges from D1 to E1 of England (Hill, 1938). 4) Kueichouphyllum yabei, an important member of the Ichinotani fauna, also characterizes the Onimaru series. 5) Heterocaninia yüi closely resembles $H$. tholusitabulata which is common in the Shangssuan. 6) Hexaphyllia sp. is an ally of $H$. mirabilis (Duncan) confined to the Visean of Europe. 7) Clisiophyllum (Clisaxophyllum) sp. more or less approaches the Chinese C. yengtzense (Yoh). 8) Fusulinids are allied with those from the Upper Chesterian of North America (Igô, 1957).

The next younger Millerella bigemmicula-Pseudostaffella kanumai zone yielded only poorly preserved Lophophyllidium sp.; fusulinid fauna shows its Lower Pennsylvanian age (Igô, 1957).

Another rich coral fauna in the black limestone with scattered specimens of Profusulinella is full of Chaetetes stocks, with Dorlodotia fujimotoi Igô (MS), Geyrophyllum carbonarium Igô (MS) in association. Caninia pseudoyohi Igô (MS) from the Profusulinella limestone of Mizuboradani valley may occupy a slightly higher stratigraphic position. The coral fauna of the Profusulinella zone does not contain any survivals from that of the lower zone.

Dorlodotia fujimotoi is more or less related to certain species of Lithostrotionella and Thysanophyllum from the Nagaiwa formation of the Kitakami massif and other lower Middle Carboniferous rocks, so far as internal structure is concerned. Geyrophyllum carbonarium is the oldest form known of the genus. The unnamed species of Chaetetes 
closely resembles, if not conspecific with, C. nagaiwaensis Minato which is the most characteristic species of the Nagaiwa. The Nagaiwa formation and this limestone are similar in fusulinid fauna.

The next younger prolific coral fauna occurs in the upper part of the zone of Fusulinella; it comprises:

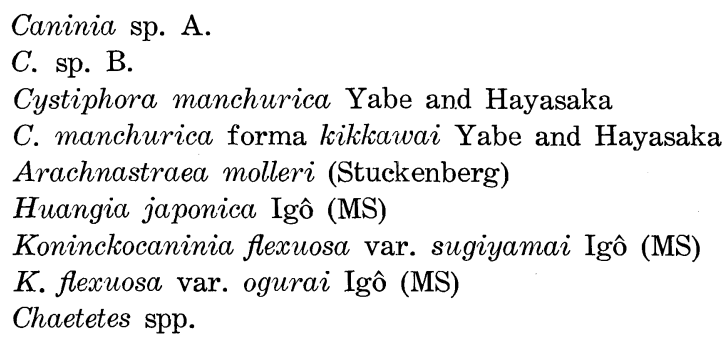

Huangia japonica and two unidentified species of Caninia occur in a horizon immediately below that of the others mentioned above. Two new varieties of Koninckocaninia are characteristic to this zone and closely related to $K$. flexuosa Dobrolyubova which is restricted to $\mathrm{C}_{2}^{3}$ at Stshurova in the Moscow Basin. Arachnastraea molleri once reported by Kamei (1952) may be from this horizon; it was first described from the Podolsk horizon of the Moscow Basin and then from the Penchi series of South Manchuria. Cystiphora manchurica and forma kikkawai occur in the Penchi series, and related forms are recorded from the Podolsk and Myatshcovo horizons of Soviet Russia. Minato (1955) reported C. manchurica forma kikkawai from the Ichinotani formation, thereby claiming its early Permian age; in the writers' collection, there are in abundance advanced forms of Fusulinella in association with these corals. Huangia japonica, dominant over unnamed species of Chaetetes is somewhat related to certain species of "Corwenia" from the Middle Carboniferous Weinigian of China. These paleontological evidences allow the correlation of this fauna to the Moscovian, and the common occurrence of Cystiphora, Arachnastraea, and Koninckocaninia certainly indicates a direct faunal connection by the water way then existed between Japan and the Ural Geosyncline via South Manchuria. The present writers agree well with Minato concerning this paleogeographic condition during the Middle Carboniferous age. At the same time, importance of Caninia and Huangia can not be ignored in the relation to the Weinigian coral fauna of South China.

The succeeding Fusulina zone and Triticites zone yield corals very rarely; only Lonsdaleoides? sp., "Campophyllum"? sp., and Chaetetes spp. have been found in the former, and several unidentified caninids and Chaetetes sp. in the latter.

The stratigraphic distribution of these corals from the Ichinotani formation is shown in the annexed table. 


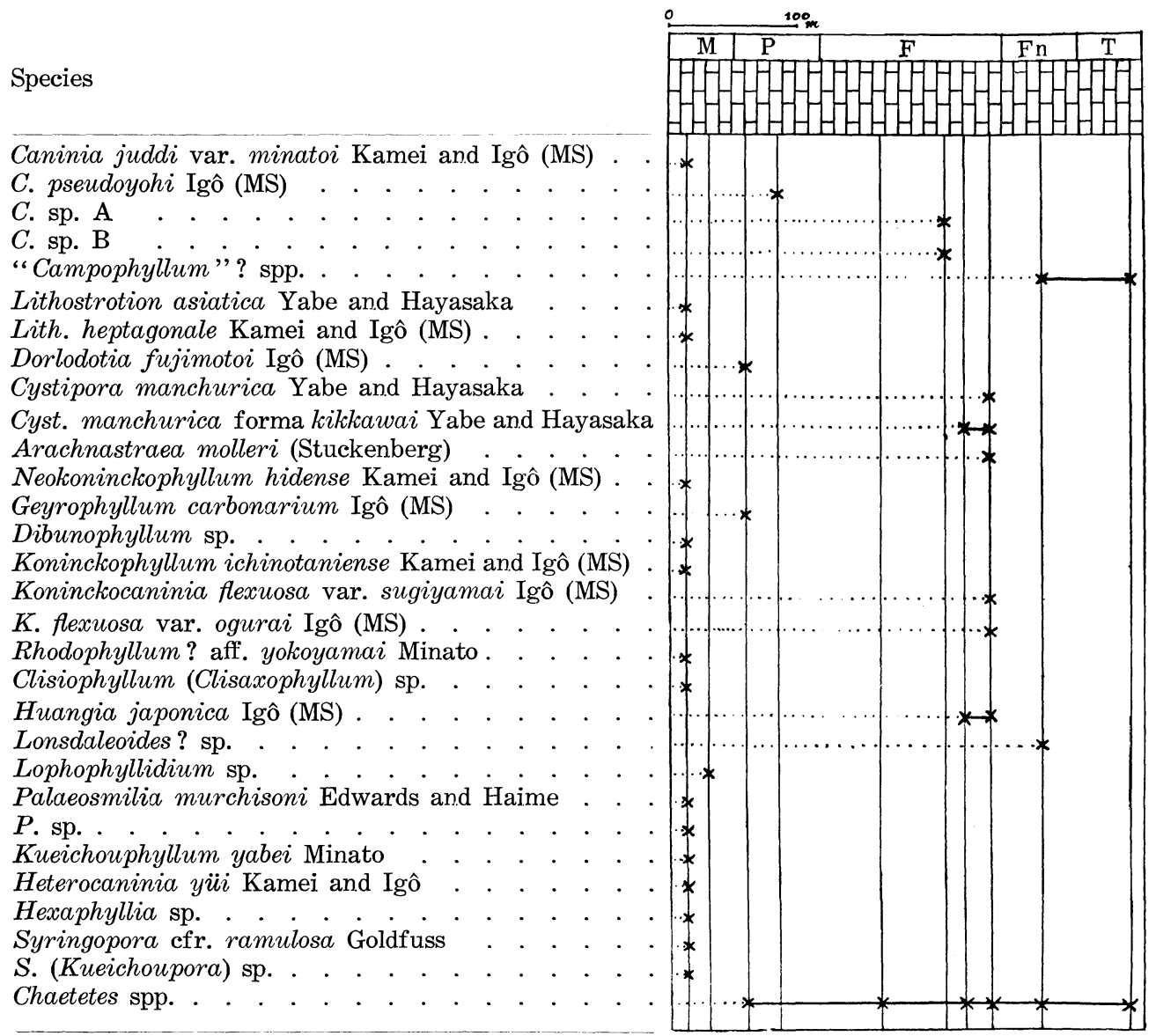

M: Zone of Millerella; P: Zone of Profusulinella; F: Zone of Fusulinella; Fn: Zone of Fusulina; T: Zone of Triticites

All species cited above in MS nom are described in another paper to be published in near future.

\section{References}

Chi, Y. S. (1936): Weinigian (Middle Carboniferous) corals of China, Pal. Sinica, ser. B, 12, fasc. 5, 1-70.

- (1935): Additional fossil corals from the Weinigian limestones of Hunan, Yunnan, and Kwangsi provinces in southwestern China, Ibid., 12, fasc. 6, 1-38.

Dobrolyubova, T. A. (1937): Simple corals of the Myatshcovo and Podolsk horizons of the Middle Carboniferous of the Moscow Basin, Acad. Sci. U. S. S. R., Inst. Sci. Min. Econ., Trav. Inst. Pal., 6, 1-92.

Hill, D. (1938-1940): A monograph on the Carboniferous rugose corals of Scotland, Pal. Soc. London, parts 1-3, 1-204.

Igô, H. (1957): Fusulinids of Fukuji, southeastern part of the Hida massif, central Japan, Tokyo Univ. Education, Sci. Rep., sec. C, 5, 153-311.

Kamei, T. (1952): The stratigraphy of the Paleozoic rocks of the Fukuji district, southern part of the Hida mountainlands, Jour. Shinshu Univ., 2, 45-74. 
Lee, J. S., Chen, S., and Chi, Y. S. (1930): Huanglung limestone and its fauna, Nat. Res. Inst. Geol. Mem., no. 9, 90-136.

Moore, R. C., and Jeffords, R. M. (1945): Description of Lower Pennsylvanian corals from Texas and adjacent states, Texas Univ. Publ., 4401, 63-208.

Minato, M. (1955): Japanese Carboniferous and Permian corals, Jour. Fac. Sci. Hokkaido Univ., ser. IV, no. 2, 1-202.

Minato, M., and Kato, M. (1957): On the Carboniferous coral zones at Fukuji, Gifu prefecture, central Japan, Proc. Japan Acad., 33, 547-552.

Stuckenberg, A. (1895): Korallen und Bryozoen der Steinkohlenablagerungen des Ural und des Timan, Com. Géol. St. Petersbourg, Mém., 10, 1-244.

Yabe, H., and Hayasaka, I. (1915-1916): Paleozoic corals from Japan, Korea, and China, Jour. Tokyo Geol. Soc., 22-23.

Yabe, H., and Eguchi, M. (1944): Corals from the Penchi coal field, Manchuko, Jour. Geol. Soc. Japan, 51, 72-76, pl. 3.

Yü, C. C. (1933): Lower Carboniferous corals of China, Pal. Sinica, ser. B, 12, 1-212.

- (1934): Descriptions of corals collected from the Mapping and Huanglung limestones in South China, Nat. Res. Inst. Geol. Mem., no. 14, 55-72. 